\section{"A Physical Education Teacher Is Like...": Examining Turkish Students' Perceptions of Physical Education Teachers Through Metaphor Analysis}

\author{
Hasan Sözena,*, Ezel Nur Korur ${ }^{b}$
}

\begin{tabular}{ll}
\hline Received: & 20 September 2019 \\
Revised: $\quad 5$ October 2019 \\
Accepted: $\quad 19$ November 2019 \\
ISSN: 1307-9298 \\
Copyright (C) IEJEE \\
www.iejee.com
\end{tabular}

DOI: 10.26822/iejee.2019257665

\begin{abstract}
The aim of this study was to determine middle school students' perceptions of physical education teachers (PETs) through metaphors and drawings. This was a qualitative study in which phenomenology and purposeful sampling were used. The study sample consisted of 200 middle school students in Ordu/Turkey in the 2017-2018 and 2018-2019 academic years. For data collection, participants were asked to fill in the blanks in the statement "The PET is like___ because__ and to draw a picture reflecting their perceptions of physical education teachers. Data were analyzed using content analysis. The steps of data analysis were naming, elimination, categorization, establishing validity and reliability, calculating the frequencies of metaphors and interpreting the drawings. Expert opinion was also used in the elimination and categorization steps. Participants' metaphors and drawings were grouped under 20 and 13 categories, respectively. Participants mostly generated metaphors under the categories of "PET as an athletic and physical force" (16\%), "PET as a good person" (12.5\%) and "PET as a guide" (9.5\%). Participants mostly drew pictures under the categories of "PET as an athletic and physical force" (18.5\%), "PET as a helpful person" (12.5\%) and "PET as a good person" (11.5\%). Participants' perceptions of PETs did not differ by variables considered.
\end{abstract}

Keywords: Physical Education Teacher, Metaphor, Perception, Secondary Education, Physical Education Lesson.

\section{Introduction}

Metaphor is defined as using a word or concept in a manner other than accepted. Metaphor can be expressed as using another concept while explaining one concept or benefiting from the features of that concept. According to these explanations, in its most general definition, the metaphor provides the opportunity to tell the unknown through the known and to make the phenomenon known from the analogies of a phenomenon, and to see a phenomenon as another phenomenon (Yilmaz, Esenturk, Demir \& Ilhan, 2017; Toptaş \& Gözel, 2018). Over the past decade, research on the development of figurative language has expanded considerably. Efforts continue to show the cognitive foundations of the ability to understand figurative language and to show the role of metaphor in the development of the metaphor. Metaphor is now considered a central aspect of language and thought and is therefore a crucial variable in cognitive development. Literature supports the claim that any theory of language acquisition can no longer ignore how children can recognize the difference between what they say and what they mean, and how people can comprehend what they mean when they say what they mean (Winner, 2017). Information at the cognitive level becomes an act of speaking ability, and mental representations are embodied through communication with the help of metaphor among children (Karaırmak, 2015).

Physical education is an integral part of education and its one of the main objectives is to enable people to develop a healthy lifestyle. It encourages especially children and young people to be engaged in physical activity and teaches them athletic skills that provide them with a healthy lifestyle. It improves not only physical skills, but also social, emotional and cognitive skills and ethics (Karaşahinoğlu, 2015). Teaching physical education effectively is a complex task that requires a deep understanding of the characteristics of the students taught, how learning takes place, the content to be taught, differentiated pedagogy and curriculum (Ward, Kim, Ko \& Li, 2014).
Physical education is a critical component considering the role that it plays in teaching students such social skills as cooperation, accepting defeat and fair play. Physical activity reinforces self-confidence, promotes mental health, strengthens social connections, facilitates interaction with peers and teachers, and reduces stress (Sözen, 2012; Brusseau \& Hannon, 2015).

Teachers play a key role in making students good citizens who contribute to society. Only qualified teachers can raise healthy and productive people. Children and young people view certain adults as role models to learn life and develop identity, and teachers are important role models for students (Wood, 2012). Physical education focuses on education as a whole, and physical education teachers (PETs) play a critical role in this process. Therefore, PETs should have professional competence and display exemplary behavior.

Middle school is a time of transition from child to young adult. It is, therefore, critical for students, who are very energetic and mobile at that period, to be engaged in physical activity (Kaya,2010). Physical and psychomotor skills affect adolescents' self-perceptions and relationships deeply. Games and sporting events provide them with the opportunity to show that they are capable of physical activities. Egocentric (self-centered) thinking becomes adolescents' main perspective, therefore, their own thoughts and worldviews become the only things that matter to them. However, they also need adult role models to emulate in order to make good choices and to become contributing adults in society. Role models who accept adolescents for who they are, love and respect them, and give them confidence and support, contribute tremendously to their development (Erden \& Akman, 2014). Considering the fact that students spend more time with their peers and teachers than their family members, teachers should be effective role models for them. Physical education discipline at early ages is an ideal foundation for health promotion and a lifelong sports habit. Physical education is 
one of the rare courses that promotes health, high quality of life, structured lifestyle and social relations. Therefore, the content, achievements and implementation of physical education course are of paramount significance for creating a disciplined and healthy society.

Teaching requires expertise; however, PETs should be more knowledgeable in their field because they help students develop cognitively, emotionally and psychomotor skills. Determining student needs and interests contributes to the success of teachers, and therefore, education. One step to achieve this is to determine students' perceptions of teachers.

There are many studies on students' perceptions of teachers (Farrell, 2006; Nikitina \& Furuoka, 2008; Aykaç, 2012; KalyonCu, 2012; Ada, 2013; Çulha-Özbaş \& Aktekin, 2013; Gedikli, 2014). Unlike other branch teachers, the area of responsibility of PETs extends beyond the boundaries of school and affects students' athletic achievements in the future. It is, therefore, important to determine students' perceptions of PETs. The number of studies investigating middle school students' perceptions of PETs through metaphors is limited in Turkey. We therefore believe that this study will contribute to the literature. The aim of this study is to determine middle school students' metaphorical perceptions of PETs. To this end, participants were asked to generate metaphors and draw pictures that described their PETs.

PETs interact more closely with students, and therefore, have a different position in the eyes of other teachers, school administrators, parents and, most importantly, students themselves. Given that students view their teachers as role models, the communication between them should be proper and healthy. It is, therefore, important to determine students' attitudes towards PE lesson and their perceptions of PETs.

\section{Method}

Research Goal

In this study, qualitative design was used to determine middle school students' perceptions of PETs through metaphors and drawings. In qualitative research, perceptions and events are revealed as they are in a realistic and wholesome manner (Yıldırım \& Şimşek, 2013). Phenomenology was used to answer the research question. The phenomenological study attempts to understand and attain a description from the students regarding the perception of individuals and lived experience of individuals about the phenomenon (Baytak, Tarman \& Ayas, 2011). The phenomenon is PET in this study.

\section{Sample and Data Collection}

The study sample consisted of 50 fifth-, 50 sixth-, 50 seventhand 50 eighth graders of four middle schools in Ordu/Turkey in the 2017-2018 and 2018-2019 academic years. Participants were recruited using maximum variation sampling, which is a purposeful sampling method used to make sure that the widest possible variety of subjects are represented in order to capture different themes, views and opinions on a phenomenon of interest (Büyüköztürk, Çakmak, Kılıç, Akgün, Karadeniz \& Demirel, 2018). Table 1 shows the demographic characteristics of the participants.

At the first stage of data collection, demographic characteristics were recorded. At the second stage of data collection, participants were asked to fill in the blanks in the statement "The PET is like__ because__ and to draw a picture reflecting their perceptions of them.

The analysis of metaphors produced by the participants was carried out in six stages: (1) naming stage, (2) elimination phase, (3) category development phase, (4) validity and reliability stage, (5) calculation and interpretation of frequencies of metaphors obtained, (6) examination of drawings made. The students categorized the metaphors were created as positive or negative by the researcher.

Table 1. Demographic Characteristics

\begin{tabular}{|c|c|c|c|}
\hline Student & & $n$ & $\%$ \\
\hline \multirow{2}{*}{ Gender } & Girl & 112 & 56 \\
\hline & Boy & 88 & 44 \\
\hline \multirow{4}{*}{ Grade Level } & 5. & 50 & 25 \\
\hline & 6. & 50 & 25 \\
\hline & 7. & 50 & 25 \\
\hline & 8. & 50 & 25 \\
\hline \multirow{2}{*}{ Engagement in Physical Activity } & Yes & 82 & 41 \\
\hline & No & 118 & 59 \\
\hline Total & & 200 & 100 \\
\hline
\end{tabular}

\section{Analyzing of Data}

Data were analyzed using content analysis, which is the codification, categorization, quantification and systematic analysis of written and oral materials (Balcl, 2011). In content analysis, data are encoded and classified accordingly. Themes describing data and grouping codes under specific categories are then developed. Therefore, at the stage of data analysis, researchers were consulted to determine whether participants' metaphors and drawings represent the conceptual categories in which they are. The categories developed by two researchers who were not involved in the study and those developed by the researcher carrying out the study were compared, and interrater reliability was calculated using the formula suggested by Miles and Huberman (Miles \& Huberman, 1994).

In studies with phenomenological approach, data are obtained directly after the data is obtained and important explanations, sentences and quotations are made to understand how the phenomenon is experienced. This step is called listing key phrases. Then, meaning groups are developed within the themes based on these important expressions (Creswell, 2013). The data collected in this study were analyzed by content analysis method. Content analysis is a systematic analysis of written and oral materials. Content analysis is the process of quantifying (digitizing) the people's words and their writings according to clear instructions (Straus \& Corbin, 1990). The essence of this approach lies in the categorization of what is written and said (Balcl, 2011).

The data collected in the content analysis is coded and classified according to these codes. Then there are themes that can explain the data at a general level and collect the codes under certain categories. In order to find the themes, the codes are first put together and the common points between them are tried to be found. This is a thematic coding process and is the categorization of the collected data by means of codes. If the number of themes that come up after the codes are put together is too high, then it can be classified for a top theme based on the common relations of these themes. It should be noted whether the various parts of the data set are represented effectively according to the emerging themes. At this stage, it is considered useful if an external researcher reflects an adequate set of data, and that the data are analyzed effectively in accordance with these themes and make suggestions to the researcher (Yıldırım \& Şimşek, 2013).

\section{Results}

Participants generated the highest number of metaphors under the category of "PET as an athletic and physical force" followed by "PET as a good person" and "PET as a guide". Some examples are as follows: 
Table 2. Participants' Metaphors for PETs and Conceptual Categories of Metaphors

\begin{tabular}{|c|c|c|c|}
\hline Categories & Metaphors & $n$ & $\%$ \\
\hline PET as an athletic and physical force & Athlete (15), Volleyball (7), Basketball (2), Ball (3), Coach (4), Mermaid (1) & 32 & 16 \\
\hline PET as a good person & Cotton (3), Cotton Candy (1), Diamond (2), Flower (9), Sun (7), Fairy Godmother (3) & 25 & 12.5 \\
\hline PET as a guide & Guide (3), Stars (10), Sun (6) & 19 & 9.5 \\
\hline PET as an angry person & Sun (9), A Bundle of Nerves (6), Fireball (1) & 16 & 8 \\
\hline PET as a friend & Friend, Pal (14) & 14 & 7 \\
\hline PET as a lazy person & Basketball Hoop (7), Castle (3), Billet (1), Armchair (1) & 12 & 6 \\
\hline PET as family member & Father (5), Parents (2) Mother (3) & 10 & 5 \\
\hline PET as an instructor & Teacher (4), Tree Root (2), Health Instructor (4) & 10 & 5 \\
\hline PET as a source of information & Light (3), Brain (1), Lighthouse (3) & 7 & 3.5 \\
\hline PET as a friendly and caring person & Heart of Gold (7) & 7 & 3.5 \\
\hline PET as an element of affection & A Ball of Love (3), Atatürk (2), Tree (2) & 7 & 3.5 \\
\hline PET as a molder & Life Coach (3), Mirror (3) & 6 & 3 \\
\hline PET as a coach & Trainer (6) & 6 & 3 \\
\hline PET as a fair person & Referee (3), King (2) & 5 & 2.5 \\
\hline PET as a disciplined and hard-working person & Commander (5) & 5 & 2.5 \\
\hline PET as an unsteady person & Cloud (1), Chameleon (4) & 5 & 2.5 \\
\hline PET as someone fun & Comedian (2), Artist (2), Summer Vacation (1) & 5 & 2.5 \\
\hline PET as a hero & Superman (3), Angel (1) & 4 & 2 \\
\hline PET as a source of life & Life (3) & 3 & 1.5 \\
\hline PET as an unjust person & Unjust (2) & 2 & 1 \\
\hline Total & & 200 & 100 \\
\hline
\end{tabular}

Student 1- The PET is like a basketball player because he is very tall and very skillful.

Student 2- The PET is like cotton because he is very softhearted.

Student 3- The PET is like the sun because he enlightens us with his knowledge.

Student 4- The PET is like the sun because he sometimes gets mad.

Student 5- The PET is like a friend because he helps us.

Student 6- The PET is like a basketball loop because he is idle and hollow.

Student 7- The PET is like a father because he is always nice to us.

Student 8- The PET is like a teacher because he is a teacher.

Student 9- The PET is like a lighthouse because he lights the way for our future.

Student 10- The PET is like a good person because he helps everybody and never gets mad.

Student 11- The PET is like the beginning of summer vacation because he entertains me a lot.

Student 12- The PET is like a mirror because he we fix ourselves by looking at him.

Table 3. Participants' Perceptions of PETs by Gender

\begin{tabular}{lrrrr}
\hline \multirow{2}{*}{ Metaphor Category } & \multicolumn{4}{c}{ Gender } \\
\cline { 2 - 5 } & \multicolumn{2}{c}{ Girl } & \multicolumn{3}{c}{ Boy } \\
\cline { 2 - 5 } & $\mathrm{n}$ & $\%$ & $\mathrm{n}$ & $\%$ \\
\hline Positive & 98 & 87.50 & 67 & 76.13 \\
\hline Negative & 14 & 12.50 & 21 & 23.86 \\
\hline Total & 112 & 100 & 88 & 100 \\
\hline
\end{tabular}

Female participants generated 98 positive 14 negative metaphors while male participants generated 67 positive and 21 negative metaphors for PETs (Table 3).

Table 4. Participants' Perceptions of PETs by Grade Level

\begin{tabular}{lrrrrrrrrr}
\hline & \multicolumn{10}{c}{ Gender } \\
\cline { 2 - 10 } Metaphor & \multicolumn{1}{c}{5} & \multicolumn{1}{c}{6} & & 7 & & 8 \\
\cline { 2 - 10 } & & $\mathrm{n}$ & $\%$ & $\mathrm{n}$ & $\%$ & $\mathrm{n}$ & $\%$ & $\mathrm{n}$ & $\%$ \\
\hline Positive & 98 & 87.50 & 67 & 76.13 & 98 & 87.50 & 67 & 76.13 \\
\hline Negative & 14 & 12.50 & 21 & 23.86 & 14 & 12.50 & 21 & 23.86 \\
\hline Total & 112 & 100 & 88 & 100 & 112 & 100 & 88 & 100 \\
\hline
\end{tabular}

The number of positive or negative metaphors generated by participants did not differ by grade level (Table 4).

Table 5. Participants' Perceptions of PETs by Engagement in Sports

\begin{tabular}{lrrrr}
\hline & \multicolumn{4}{c}{ Engagement in Sports } \\
\cline { 2 - 5 } Metaphor Category & \multicolumn{2}{c}{ Yes } & \multicolumn{3}{c}{ No } \\
\cline { 2 - 5 } & $\mathrm{n}$ & $\%$ & $\mathrm{n}$ & $\%$ \\
\hline Positive & 82 & 91.11 & 83 & 75.45 \\
\hline Negative & 8 & 8.88 & 27 & 24.54 \\
\hline Total & 90 & 100 & 110 & 100 \\
\hline
\end{tabular}

$91.11 \%$ (82) of 90 metaphors generated by participants engaged in sports were positive while $75.45 \%$ (83) of 110 metaphors generated by participants not engaged in sports were positive.

Participants mostly drew pictures under the categories of "PET as an athletic and physical force" ( $n=37,18.5 \%)$, "PET as a helpful person" ( $n=25,12.5 \%)$, "PET as a good person" $(n=23,11.5 \%)$ and "PET as an angry person" $(n=23,11.5 \%)$ (Table 6). Some examples are as follows: 
Table 6. Participants' Drawings and Their Conceptual Categories

\begin{tabular}{lrr}
\hline Categories & $\mathrm{n}$ & $\%$ \\
\hline PET as an athletic and physical force & 37 & 18.5 \\
\hline PET as a helpful person & 25 & 12.5 \\
\hline PET as a good person & 23 & 11.5 \\
\hline PET as an angry person & 23 & 11.5 \\
\hline PET as a motivator & 20 & 10 \\
\hline PET as a guide & 14 & 7 \\
\hline PET as a lazy person & 13 & 6.5 \\
\hline PET as an instructor & 12 & 6 \\
\hline PET as a game partner & 9 & 4.5 \\
\hline PET as someone fun & 8 & 4 \\
\hline PET as an element of affection & 8 & 4 \\
\hline PET as an just person & 5 & 2.5 \\
\hline PET as an unjust person & 3 & 1.5 \\
\hline Total & 200 & 100 \\
\hline
\end{tabular}

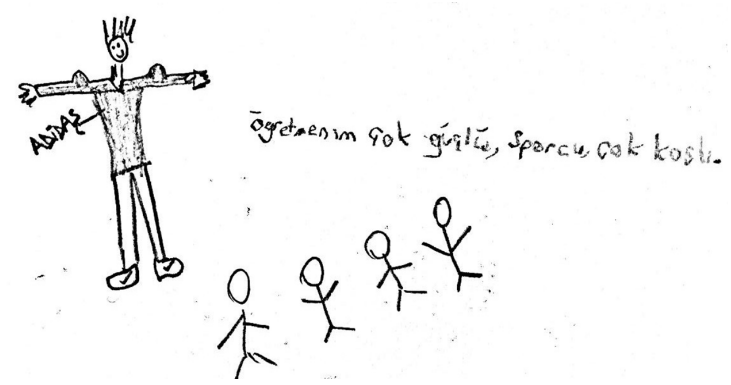

Figure 1. Student 1 - "My teacher is very strong, athletic and very muscular". PET as an athletic and physical force

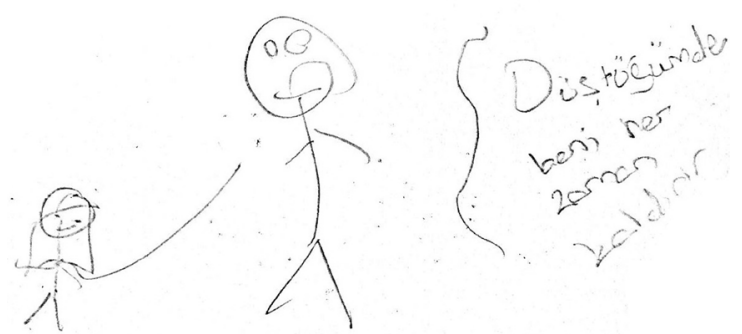

Figure 2. Student 2 - "He always lifts me up when I fall". PET as a helpful person
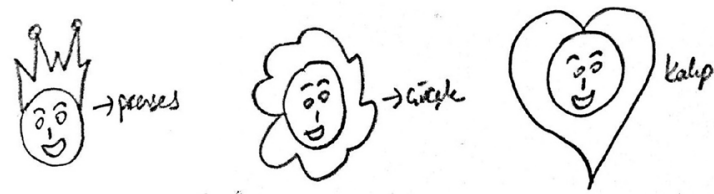

Figure 3. Student 3 - "Princess, flower, heart". PET as a good person

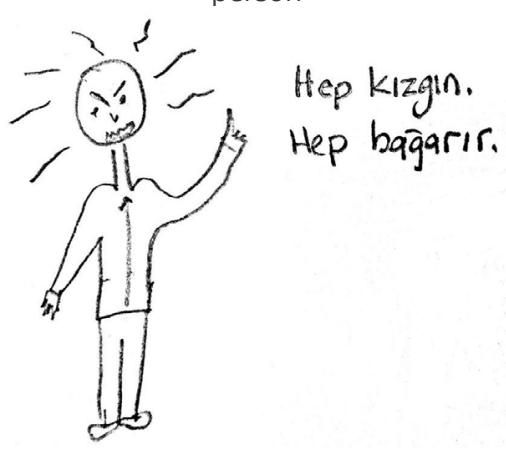

Figure 4. Student 4 - "He is always angry, he always shouts". $\mathrm{PET}$ as an angry person

\section{Discussion}

The highest number of metaphors that participants generated for PETs was under the category of "PET as an athletic and physical force". Participants mostly used sports terms such as volleyball, basketball, athlete etc. to describe their PETs. According to these results, enabling students to see their PET as an athlete can increase the participation of students as a role model. Research shows that students generally generate positive metaphors for PETs in the literature (Kalyoncu, 2012; Soysal \& Afacan, 2012; Gedikli, 2014; Sengül, Katrancı \& Cantimer, 2014; Çulha-Özbaş \& Aktekin 2013; Sayar, 2014). However, Koç et al., (2015) and Karaşahinoğlu (2015) reported that the clear majority of students generated negative metaphors for PETs.

Participants generated 16 metaphors under the category of "PET as an angry person". In their explanations, they described their PET as someone who always yells at them, speaks loudly and shouts. Karaşahinoğlu (2015) reported a similar finding and concluded that this type of behavior results in fear, anxiety and alienation in students. Similarly, Ada (2013) reported that the second highest number of metaphors generated by students regarding their math teachers was under the category of math teacher as a bad person.

Girls who participated in the study produced more negative metaphors than boy students. However, the difference was not statistically significant. Ada (2013) and Karaşahinoğlu (2015) did not report any gender differences in a study they conducted.

The number and nature (positive or negative) of metaphors generated by participants did not differ by grade level. The number and nature of metaphors generated by participants did not differ by engagement in sports. This result was contrary to our expectations that students engaged in sports would be likely to have more positive perceptions of PETs than those not engaged in sports.

The highest number of pictures that participants drew to describe PETs was also under the category of "PET as an athletic and physical force". This result indicates that they have positive perceptions of PETs in general. However, the presence of negative metaphors and drawings may require further investigation. Aykaç (2012) investigated primary school students' perceptions of teachers and learning process and reported that their drawings of teachers were mostly positive, which was also observed in our study.

Participants mostly generated metaphors under the categories of "PET as an athletic and physical force" $(n=32,16 \%)$, "PET as a good person" ( $n=25,12.5 \%)$, "PET as a guide" $(n=19,9.5 \%)$ and "PET as an angry person" ( $n=16,8 \%)$.

The pictures that participants drew to describe PETs were under the categories of "PET as an athletic and physical force" $(n=37,18.5 \%)$, "PET as a helpful person" $(n=25,12.5 \%)$, "PET as a good person" ( $n=23,11.5 \%)$ and "PET as an angry person" $^{\prime \prime}(n=23,11.5 \%)$. According to these results, participants' perceptions of PETs did not differ by gender, grade level and engagement in sports.

However, the main issue in our research is to determine the role of physical education teacher in the education curriculum. It aims to follow the same educational curriculum in all schools of the Turkish education system which is within the scope of a central education. The physical education teacher has similar approaches in this training curriculum, and this is controlled within the management approach. These metaphors created by the students are metaphors against the physical education course in the middle school curriculum. 


\section{Conclusion}

In this study, participants were asked to generate metaphors and draw pictures to describe PETs. As a proposal for future studies; students may be asked to ask open-ended questions and / or keep reflective diaries to increase the power of research. A similar study can be applied to students of different educational levels. In addition, students' perceptions of male and female PETs can be analyzed separately. The results from these and similar studies can be evaluated to provide information to institutions training PETs. Considering the presence of negative metaphors, in-service seminars for PETs can be revised and modified.

\section{Acknowledgements}

We would like to thank all the subjects who volunteered their time to participate in this study.

\section{References}

Ada, S. (2013). Öğrencilerin matematik dersine ve matematik ögretmenine yönelik algılarının metaforlar yardımıyla belirlenmesi. Unpublished Master's Thesis, Gazi University, Graduate School of Educational Sciences, Ankara, Turkey.

Aykaç, N. (2012). İlköğretim öğrencilerinin resimlerinde öğretmen ve öğrenme süreci algısı. Eğitim ve Bilim, 37(164), 298-315.

Balcı, A. (2011). Sosyal bilimlerde araştırma: yöntem, teknik ve ilkeler. Ankara: Pegem.

Baytak A., Tarman, B., \& Ayas, C. (2011). Experiencing technology integration in education: children's perceptions. International Electronic Journal of Elementary Education, 3(2), 139-151.

Brusseau, T.A., Hannon, J.C. (2015). Impacting children's health and academic performance through comprehensive school physical activity programming. International Electronic Journal of Elementary Education, 7(3), 441-450.

Büyüköztürk, Ş., Çakmak Kılıç, E., Akgün, Ö.E., Karadeniz, Ş., \& Demirel, F. (2018). Bilimsel Araştırma Yöntemleri. Ankara: Pegem Akademi.

Creswell, J.W. (2013). Research Design Qualitative, Quantitative, And Mixed Method Approaches. London: SAGE Publications.

Çulha- Özbaş, B. \& Aktekin, S. (2013). Tarih öğretmen adaylarının tarih öğretmenliğine ilişkin inançlarının metafor analizi yoluyla incelenmesi. Journal of Theory and Practice in Education / Eğitimde Kuram ve Uygulama, 9(3), 211-228.

Erden, M. \& Akman, Y. (2014). Eğitim Psikolojisi. Ankara: Arkadaş.

Farrell, T.S.C. (2006). 'the teacher is an octopus: Uncovering preservice English language teachers' prior beliefs through metaphor analysis. RELC Journal, 37(2), 236248.

Gedikli, Ö. (2014). Ortaokul 2, 3 ve 4. sınıf öğrencilerinin Türkçe öğretmenini algılayışının metaforlar aracılığıyla belirlenmesi. Unpublished Master's Thesis, Karadeniz Technical University, Trabzon, Turkey.
Kalyoncu, R. (2012). Görsel sanatlar öğretmeni adaylarının "öğretmenlik" kavramına ilişkin metaforları. Mustafa Kemal Üniversitesi Sosyal Bilimler Enstitüsü Dergisi, 9(20), 471-484.

Karaırmak, Ö. (2015). Çocukla psikolojik danışmada metaforik süreç. Türk Psikolojik Danışma ve Rehberlik Dergisi, 5(43), 115-127.

Karaşahinoğlu, T. (2015). Ortaokullarda Beden Eğitimi Öğretmenine ilişkin Metaforik Algılar. Unpublished Master's Thesis, Gazi University, Graduate School of Educational Sciences, Ankara, Turkey.

Kaya, A. (Ed.). (2010). Eğitim psikolojisi. Ankara: Pegem.

Koç, M., Murathan, F., Yetiş, Ü. \& Murathan, T. (2015). ilköğretim 7. sınıf öğrencilerinin spor kavramına ilişkin algıları. Akademik Sosyal Araştırmalar Dergisi, 3(9), 294- 303.

Miles, M. B. \& Huberman, A. M. (1994). An expanded sourcebook qualitative data analysis. California: Sage Publications.

Nikitina L., \& Furuoka F. (2008). "A language teacher is like. .." examining Malaysian students' perception of language teachers through metaphor analysis. Electronic Journal of Foreign Language Teaching, 5(2), 192-205.

Sayar, E. (2014). Investigating EFL teachers' and their students' conceptions of Professional teacher identity through metaphor analysis. Master Thesis, Abant Izzet Baysal University Institute of Educational Sciences, Bolu, Turkey.

Şengül, S., Katrancı, Y. \& Cantimer, G. (2014). Ortaöğretim Öğrencilerinin Matematik Öğretmeni Kavramına iliş̧kin Metafor Algıları. The Journal of Academic Social Science Studies, 25(1), 89-111.

Soysal, D. \& Afacan, Ö. (2012). Illköğretim öğrencilerinin "fen ve teknoloji dersi" ve "fen ve teknoloji öğretmeni" kavramlarına yönelik metafor durumları. Mustafa Kemal Üniversitesi Sosyal Bilimler Enstitüsü Dergisi, 9(19), 287-306.

Sözen, H. (2012). The effect of physical education and sports school training on problem solving skills of the athletes. Procedia- Social and Behavioral Sciences, 46, 4186-4190.

Straus, A. L., Corbin, J. (1990). Basic of qualitative research: Grounded theory procedures and techniques. Newbury Park, CA: Sage.

Toptaş, V., Gözel, E. (2018). Investigation of the metaphorical perceptions of the parents on the concept of mathematics. International Electronic Journal of Elementary Education, 10(5), 621-626.

Ward P., Kim I., Ko B., Li W. (2015). Effects of improving teachers' content knowledge on teaching and student learning in physical education. Research Quarterly for exercise and Sport, 86(2), 130-139.

Winner, E. (Ed.). (1996). Developmental Perspectives on Metaphor. New York: Psychology Press.

Wood, TD. (2012). Teacher perceptions of gender-based differences among elementary school teachers. International Electronic Journal of Elementary Education, $4(2), 317-345$. 
Yıldırım, A. \& Şimşek, H. (2013). Sosyal bilimlerde nitel araştırma yöntemleri. Ankara: Seçkin.

Yilmaz, A., Esenturk, O.K., Demir, G.T., Ilhan E.L. (2017). Metaphoric perception of gifted students about physical education course and physical education teachers. Journal of Education and Learning, 6(2): 220-234. 